deny having taken aspirin, though the dose is often exaggerated or understated. Consciousness may be impaired in young children.

Clinical assessment of the severity of the poisoning is unsatisfactory and of no prognostic value, ${ }^{5-8}$ and the plasma level of salicylate is the best indicator. ${ }^{169}$ The time since ingestion must also be taken into account to allow for the effects of absorption, excretion, and biotransformation of the drug. A correction formula devised by A. K. Done 6 to allow the plasma salicylate level to be considered as a function of time does not take account of variables affecting salicylate metabolism such as protein binding, intracellular dispersion, and urinary $\mathrm{pH}$, and it is therefore better to use measurements of plasma salicylate, particularly 30 minutes after gastric lavage, to establish the peak blood level.

Other important biochemical changes may present serious problems in treatment. An acid-base disturbance due to a combination of metabolic acidaemia and respiratory alkalaemia occurs in all cases. In young children metabolic acidaemia predominates but in older children and adults the arterial pH is usually normal or high. Nevertheless, some adults develop acidaemia, ${ }^{10-13}$ and A. T. Proudfoot and S. S. Brown ${ }^{14}$ found that it was associated with impaired consciousness and a grave prognosis. Acidaemic patients seem to be more prone to pulmonary oedema, cardiovascular collapse, and sudden death, and therefore in these cases the first aim must be to correct the acid-base imbalance. ${ }^{14}$ Hypokalaemia may occur, particularly in patients with a predominant alkalaemia, ${ }^{15}$ and dehydration, with fluid deficits of several litres, is common as a result of hyperpyrexia, sweating, and hyperventilation. ${ }^{16}$ In all patients who are drowsy the plasma salicylate, plasma electrolytes, and the arterial $\mathrm{pH}$ should be measured.

Intensive supportive therapy 1 and gastric lavage is needed in all patients with acute salicylate poisoning. ${ }^{1} 416$ Elimination of salicylates is required when the plasma salicylate level is above $30 \mathrm{mg} / 100 \mathrm{ml}$ in children or $50 \mathrm{mg} / 100 \mathrm{ml}$ in adults. The urinary excretion of free salicylate increases progressively with alkalinization of the urine, ${ }^{14516-20}$ and augmentation of urine flow is also important. ${ }^{16}$ Three main treatment regimens have been advocated. Forced alkaline diuresis, recommended by $\mathrm{G}$. Cumming and his colleagues, ${ }^{5}$ reduces the plasma salicylate but provokes severe and rapid changes in arterial hydrogen ion concentration and electrolytes, which require close biochemical monitoring. A. A. H. Lawson and his associates ${ }^{16}$ developed a modification of this regimen in the form of a forced diuresis which is suitable for general use, does not cause electrolyte or acid-base upsets, and requires only minimum laboratory control. A. G. Morgan and A. Polak ${ }^{13}$ suggested a less vigorous diuresis, using both bicarbonate and acetazolamide to achieve alkalinization of the urine. Though effective in removing salicylate it still requires close biochemical monitoring. Previous experience of the use of acetazolamide in aspirin poisoning ${ }^{18} 2122$ has shown that it may worsen metabolic acidaemia. Mannitol has been used to augment various diuresis regimens, ${ }^{23-26}$ but all provoke rapid fluid and electrolyte imbalance and require close biochemical control.

Peritoneal dialysis and haemodialysis may rarely be required in very severe poisoning or when there is a concurrent condition which precludes forced diuresis. ${ }^{4}$ Otherwise forced diuresis as advocated by Lawson and his colleagues ${ }^{16}$ is a safe and successful treatment in most patients, including young children provided the volumes of fluid administered are appropriately adjusted.
${ }^{1}$ Matthew, H., and Lawson, A. A. H., Treatment of Common Acute Poisonings, 2nd edn. Edinburgh, Livingstone, 1970.

2 Craig, J. O., Ferguson, I. C., and Syme, J., British Medical fournal, 1966,

3 Campbell, H., in Salicylates-An International Symposium, ed. A. St. John Dixon. London, Churchill, 1963.

4 British Medical fournal, 1969, 1, 3.

5 Cumming, G., Dukes, D. C., and Widdowson, G., British Medical Fournal, 1964, 2, 1033.

B Done, A. K., Fournal of the American Medical Association, 1965, 192, 770.

7 Smith, M. J. H., in The Salicylates. London, Interscience Publishers, 1966.

${ }^{8}$ Brown, S. S., Cameron, J. C., and Matthew, H., British Medical fournal, $1967,2,738$.

- Beveridge, G. W., Forshall, W., Munro, J. F., Owen, J. A., and Weston, I. A. G., Lancet, 1964, 1, 1406 .

10 Schreiner, G. E., Berman, L. B., Griffin, J., and Feys, J., New England Fournal of Medicine, 1955, 253, 213.

11 Ghose, R. R., and Joekes, A. M., Lancet, 1964, 1, 1409.

12 Ghose, R. R., Postgraduate Medical fournal, 1967, 43, 454.

18 Morgan, A. G., and Polak, A., British Medical fournal, 1969, 1, 16

14 Proudfoot, A. T., and Brown, S. S., British Medical fournal, 1969, 2, 547.

18 Robin, E. D., Davis, R. P, and Rees, S. B., American fournal of Medicine, $1959,26,869$.

16 Lawson, A. A. H., Proudfoot, A. T., Brown, S. S., MacDonald, R. H., Fraser, A. G., Cameron, J. C., and Matthew, H., Quarterly fournal of Medicine, 1969, 38, 31.

17 Macpherson, C. R., Milne, M. D., and Evans, B. M., British fournal of Pharmacology and Chemotherapy, 1955, 10, 484 .

18 Hoffman, W. S., and Nobe, C., fournal of Laboratory and Clinical Medicine, 1950, 35, 237 .

19 Gutman, A. B., Yu, T. F., and Sirota, J. H., fournal of Clinical Investigation, 1955, 34, 711.

20 Morgan, A. G., and Polak, A., Clinical Science, 1971, 41, 475.

21 Schwartz, R., Fellers, F. X., Knapp, J., and Yaffe, S., Pediatrics, 1959, 23, 1103.

${ }^{22}$ Feuerstein, R. C., Finberg, L., and Fleishman, E., Pediatrics, 1960, 25, 215. 23 Bloomer, H. A., Fournal of Laboratory and Clinical Medicine, 1966, 67, 898. setter, J. G., Maher, J. F., and Schreiner, G. E., Archives of Internal Medicine, 1966, 117, 224 ."

25 Prowse, K., Pain, M., Marston, A. D., and Cumming, G., Clinical Science, 1970, 38, 327 .

26 Morgan, A. G., Bennett, J. M., and Polak, A., Quarterly fournal of Medicine, 1968, 37, 589.

\section{Herpes Genitalis}

That many viruses usually live in comparative peace with their host is well illustrated by Herpesvirus hominis (herpes simplex), which may be a more constant companion of man than most viruses yet gives little or no trouble in most individuals. Herpesvirus isolated from the genital tract can be distinguished antigenically and biologically from herpesvirus isolated from non-genital sites. ${ }^{1}$ There is growing evidence that the genital, or type 2 , herpesvirus is venereally transmitted. Thus antibodies do not appear until heterosexual activity begins. Chaste women of religious orders are virtually free of these antibodies, which are most frequently found in sexually promiscuous women. Virus isolation from vaginal secretions of female sexual partners of men with genital herpes is 10 times greater than in controls, and the incidence of genital herpes is greater among women attending venereal disease clinics than among women having routine cervical cytology examination in gynaecological departments. $^{2-5}$

Herpes genitalis tends to recur and the lesions in the first infection are more marked and persist longer (2-6 weeks) than in subsequent attacks, which may last only a few days. Clinically herpes genitalis is similar to herpes occurring in other parts of the body (due to herpesvirus type 1), with grouped vesicles which often irritate and are sometimes painful. The vesicles soon rupture to form non-indurated ulcers. The common site in males is the glans penis, prepuce, and shaft of the penis and in women the external genitalia and occasionally the cervix, where it can cause severe cervicitis with necrotic ulceration. There is evidence that a carrier state exists in women, and isolation of herpesvirus type 2 has been made mostly from the cervix in the absence of signs. $^{6}$ A carrier state in men has not yet been established. 
Syphilis has to be differentiated from herpes genitalis, but the syphilitic sore is usually single, painless, and not irritating and darkground examinations for Treponema pallidum and repeated serological tests for syphilis will invariably establish the diagnosis. Other ulcerative conditions of the genitalia, including Behçet's syndrome, traumatic sores, and Lipschütz's acute vulval ulcers, may have to be considered.

A strong association between antibodies to herpesvirus type 2 and cervical neoplasia has been observed in Negro women by Z. M. Naib and his group of investigators in Atlanta, 7-9 but was less evident among Caucasian women in Texas. ${ }^{10}$ In a recent study by W. E. Rawls and colleagues ${ }^{4}$ Caucasian women of a higher socioeconomic class were compared with Negroes of a lower socioeconomic class, and it was found that $78 \%$ of the Caucasian women lacked antibodies to either herpesvirus type 1 or 2 compared with only $29 \%$ of the Negroes. When clinical genital herpes developed the antibody response to herpesvirus type 2 was similar in both groups. If there is no difference between the races in maintaining antibody titres to the virus over prolonged periods differences in the association between cervical neoplasia and antibodies to herpesvirus type 2 among the Caucasian and Negroes studied probably represent different degrees of sexual promiscuity. Naib and colleagues ${ }^{7}$ found cervical anaplasia in $23.7 \%$ of 245 women with cytological evidence of genital herpes as against $1.6 \%$ in 245 apparently uninfected women matched for age and social background. They thought that either similar factors operate independently to produce both conditions or that transmitted herpesvirus type 2 , possibly together with other factors, plays an aetiological role in transforming normal cervical cells into cancerous cells. It is of interest that herpesvirus has been shown experimentally to shorten the time required for the production of methylcholanthrene-induced papilloma in mice. ${ }^{11}$

I. Royston and L. Aurelian ${ }^{12}$ observed that antibody titres against herpesvirus type 2 were significantly higher among patients with carcinoma of the cervix than in matched controls. One possibility is that herpesvirus type 2 is a common inhabitant of the female genital tract and when invaded by cancer cells responds with increased antibody production. However, in a study outside the United States the incidence of herpesvirus type 2 antibodies was similar in patients with carcinoma of the cervix and matched controls. ${ }^{13}$ Much work will be needed to resolve these differences. At present the evidence that herpesvirus type 2 is a causal agent or even a covariable of cervical cancer is circumstantial, ${ }^{14}$ but it can be reasonably argued that it is sufficiently strong to suggest that women with known genital herpes should be followed closely by cervical screening as a special group with possibly increased risk of developing cervical anaplastic changes. It is tempting to speculate whether a similar situation exists in carcinoma of the penis, since it is infinitely more common in the uncircumcised-as is herpes of the glans penis. It might be of interest to investigate patients with cancer and precancerous conditions of the glans virologically and serologically for herpesvirus type 2 .

A. J. Nahmias and colleagues ${ }^{15}$ confirmed that the cervix was the main site of inapparent neonatal herpes infection and that the risk of infection to infants of mothers carrying the virus late in pregnancy was $60 \%$. Many of these infants died or had visceral infection with serious sequelae. In addition to the perinatal threat by genital herpes infection late in pregnancy, there are also reports of an association of abortion or congenital malformation with infection early in pregnancy. ${ }^{6} 16$ The condition is easily missed in the woman and when typical lesions are absent diagnosis rests on cytological and virus studies. Caesarean section to prevent infection of the infant is of uncertain value, since the possibility of transplacental transmission of the virus has not been excluded.

Treatment of infected infants with gammaglobulin has been disappointing. In adults local treatment with $0.5 \%$ idoxuridine has not given convincing results, but current trials using 20 and $40 \%$ idoxuridine in dimethyl sulphoxide, as suggested for herpes zoster, ${ }^{17}$ are promising. T. Nasemann $^{18}$ and later J. Söltz-Szöts ${ }^{19}$ treated recurrent herpes (though not specifically genital herpes) with a vaccine prepared from herpesvirus antigen. No further relapses occurred in $75 \%$ of the patients in each study, but confirmation will be needed under controlled conditions in such an unpredictable disease. Söltz-Szöts recently used inactivated influenza A vaccine in patients with herpes zoster and in a large group with recurrent herpesvirus infection to stimulate interferon production. The results in herpes zoster were encouraging and the report on the effect in recurrent herpesvirus infection will be awaited with great interest. Utilizing the patient to produce his own broadspectrum antiviral agent is an attractive idea.

Leaving aside the problems associated with herpes in pregnancy, genital herpes in adults will possibly prove no more than a minor, common venereal infection of both sexes with occasionally a considerable nuisance value. However, if a direct link between genital herpes and genital cancer is established the infection will become of major importance.

1 Dowdle, W. R., Nahmias, A. J., Harwell, R. W., and Pauls, F. P., fournal of Immunology, 1967, 99, 974

Nahmias, A. J., Dowdle, W. R., Naib, Z. M., Josey, W. E., McLone, D. and Domescik, G., British fournal of Venereal Diseases, 1969, 45, 294 Rawls, W. E., Tompkins, W. A. F., and Melnick, J. L., American fournal of Epidemiology, 1969, 89, 547 .

${ }^{4}$ Rawls, W. E., Gardner, H. L., Flanders, R. W., Lowry, S. P., Kaufman R. H., and Melnick, J. L., American fournal of Obstetrics and Gynecology, $1971,110,682$.

5 Beilby, J. O. W., Cameron, C. H., Catterall, R. D., and Davidson, D., Lancet, 1968, i, 1065.

- Nahmias, A. J., Josey, W. E., Naib, Z. M., Freeman, M. G., Fernandez, R. J., and Wheeler, J. H., American fournal of Obstetrics and Gynecology, 1971, 110, 825.

Naib, Z. M., Nahmias, A. J., Josey, W. E., and Kramer, J. H., Cancer, $1969,23,940$

8 Naib, Z. M., Acta Cytologica, 1966, 10, 126.

- Naib, Z. M., Nahmias, A. J., and Josey, W. E., Cancer, 1966, 19, 1026 Rawls, W. E., Iwamoto, K., Adams, E., Melnick, J. L., and Green, G. H., Lancet, 1970, 2, 1142 .

11 Tanaka, S., and Southam, C. M., Fournal of the National Cancer Institute, $1965,34,441$.

12 Royston, I., and Aurelian, L., American fournal of Epidemiology, 1970, 91,531 .

18 Iwamota, K., Adam, E., Rawls, W. E., Melnick, J. L., and Correa, P., Bacteriological Proceedings, 1970, abstr. 134, p. 174.

14 Nahmias, A. J., Josey, W. E., Naib, Z. M., Luce, C. F., and Guest, B. A., American fournal of Epidemiology, 1970, 91, 547.

15 Nahmias, A. J., Alford, C. A., and Korones, S. B., Advances in Paediatrics, Nahmias, A. J., Alf

16 South, M. A., Tompkins, W. A. F., Morris, C. R., and Rawls, W. E., Fournal of Pediatrics, 1969, 75, 13.

17 Juel-Jensen, B. E., MacCallum, F. O., Mackenzie, A. M. R., and Pike, M. C., British Medical Fournal, 1970, 4, 776.

18 Nasemann, T., Archive für Klinische und Experimentelle Dermatologie, $1970,237,234$.

10 Söltz-Szöts, J., Zeitschrift für Haut und Geschlechtskrankheiten, 1971, 46, 755.

\section{Clinical Endocrinology}

With the article by Dr. David Evered and Professor Reginald Hall on page 290 of this week's B.M.7. we start a new series of "Medical Practice" articles, entitled "Clinical Endocrinology." Besides articles on the endocrine glands themselves, 